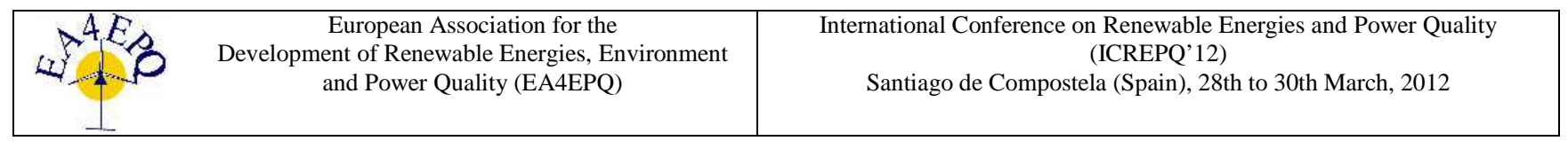

\title{
Operating conditions on the performances of SOFC fuelled with methane
}

\author{
A. Musa ${ }^{1}$, A. Agina ${ }^{2}$ and M. Talbi ${ }^{3}$ \\ ${ }^{1-3}$ Department of Marine Engineering \\ Faculty of Engineering, Tripoli University, Libya \\ Phone: +00218911547601, e-mail: musa@tripoliuniv.edu.ly
}

\begin{abstract}
Both high temperature (HT) and intermediate temperature (IT) SOFC performances are evaluated using validated models for the internally reformed (IR) fuel cells. Moreover, several SOFC cycles are proposed and investigated. A parametric study is performed to evaluate the effect of various parameters such as turbine inlet temperature, operating pressure, and fuel recirculation rate on the system performance. The HTSOFC and the IT-SOFC cycles are simulated in order to evaluate and compare their performances. The simulation results show that the electrical outputs from the SOFC and gas turbine are increased simultaneously by increasing the turbine inlet temperature. Furthermore, the efficiency for the IT-SOFC cycle is found be the higher than the efficiency for the HT-SOFC cycle.
\end{abstract}

Key words: SOFC, Gas turbine, Performance

\section{Introduction}

The Solid Oxide Fuel Cell (SOFC) is one of the most promising type of fuel cells. It is considered an excellent device for future plants, expected to produce clean electrical energy at high conversion rates, low emission and low noise levels [1]. The integration of an SOFC stack with gas turbine, compressors and heat exchangers, is a very successful application.

The operating temperature of high temperature solid oxide fuel cell (HT-SOFC) is between 950 and $1000^{\circ} \mathrm{C}$ because the YSZ solid electrolyte has low ionic conductivity at lower operating temperatures. The high operating temperature causes many serious problems, such as physical and chemical degradation of the electrode materials, and so it is desirable to develop SOFCs operating at or below $800^{\circ} \mathrm{C}$. Such operating temperatures can be achieved by using an extremely thin but dense YSZ electrolyte or a more conductive electrolyte [2]. Several recent works focused on intermediate temperature solid oxide fuel cell (IT-SOFC).

Due to the high temperature in the SOFC and the water production during the electrochemical reaction, SOFCs can allow for internal reforming. This means that natural gas is directly fed into the fuel cell, where it will convert to hydrogen. The heat necessary for this reforming reaction is delivered by the electrochemical reaction in the cell. In previously paper [3], Two types of combined cycles is investigated: a combined cycle consisting of a two-staged combination of IT-SOFC and HT-SOFC and another consisting of two stages of IT-SOFC. The simulation results show that a combined cycle of two-staged ITSOFC can give $65.5 \%$ under standard operational conditions.

In this paper, the validated numerical models for internally reformed HT and IT SOFCs are built in Aspen customer modeller and integrated in Aspen Plus ${ }^{\mathrm{TM}}$. Several SOFC cycles are proposed and investigated. Moreover, the effects of various important parameters on the system performance are evaluated. The aim of this work is to find the best configuration for SOFC system.

\section{Cycles Description}

The SOFC cells currently in operation are fuelled with natural gas. The high temperature inside the cell stacks allows for reforming the methane directly inside the cell if steam is provided at the inlet. The heat necessary for this reforming reaction is delivered by the electrochemical reaction in the cell. The pure methane $\left(\mathrm{CH}_{4}\right)$ fuel is provided at atmospheric conditions. The characteristics of the systems are given in Table I.

\section{A. Base case of SOFC/GT system}

The base case of HT-SOFC/GT system consists of fuel and air compressors, two heat exchangers, a pump, a mixer, the IR-SOFC stack, a combustor and gas turbine (as shown in Fig.1). Water and fuel are provided at atmospheric conditions. The operating principle of the system can be summarized as follows: methane and air are compressed up to the SOFC stack operating pressure by the fuel and air compressors.

Water is admitted into the heat exchangers $\mathrm{H} / \mathrm{E} 2$ to generate steam. Fuel and steam must be mixed in order to produce the mixture that will drive the internal steam reforming reaction. The mixture enters into the anode side in the stack. The compressed air from the compressor (AC) is supplied to the heat exchanger (H/E1). In the heat exchanger H/E1 the hot effluent of burned gas releases the heat necessary to preheat the cathode inlet gases of the stack. The anode and cathode gases of the SOFC stack are recycled to the combustor. No additional fuel was introduced into the combustor. 
The combustor exit gas is sent to a gas turbine, and heat exchangers $(\mathrm{H} / \mathrm{E} 1)$ and $(\mathrm{H} / \mathrm{E} 2)$ respectively. The combustor outlet temperature is $900^{\circ} \mathrm{C}$.

\section{B. HT-SOFC system}

The HT-SOFC/GT system (Fig. 2) is similar to the base case system (Fig. 1), except that the combustor exit gas is sent to a gas turbine, heat exchanger (H/E1), heat exchanger $(\mathrm{H} / \mathrm{E} 3)$ and heat exchanger $(\mathrm{H} / \mathrm{E} 2)$ respectively. In the heat exchanger H/E3 the hot effluent of burned gas releases the heat necessary to preheat methane. This preheated methane is split into two parts. The first part of the preheated methane is mixed with steam and supplied to the anode side of stack. The remaining part of the preheated methane is introduced into the combustor. The turbine inlet temperature is $1290^{\circ} \mathrm{C}$ and kept constant.

\section{SOFC/GT with anode gas recycling systems}

In this (HT or IT) SOFC/GT part of the anode gasses is recycled, as the anode gasses contain steam needed in the reforming reaction. This is a way of avoiding a steam generator in the cycle as it is adopted by [2 and 7]. The compressor (C1) is used to compensate the pressure drop through the SOFC stack (see Fig. 3).

Table I. - Input parameters and assumptions made for the SOFC system

\begin{tabular}{|l|l|}
\hline Setting parameter & Value \\
\hline Current density & $0.250 \mathrm{Acm}^{-2}$ \\
\hline Active cell area & $250 \mathrm{~m}^{2}$ \\
\hline Steam-to-carbon ratio & 2 \\
\hline $\begin{array}{l}\text { Gas turbine and pump isentropic } \\
\text { efficiencies }\end{array}$ & $85 \%$ \\
\hline $\begin{array}{l}\text { Compressors isentropic } \\
\text { efficiency }\end{array}$ & $80 \%$ \\
\hline Pressure drop in combustor & $0.2 \mathrm{bar}$ \\
\hline Pressure drop in SOFC & $0.01 \mathrm{bar}$ \\
\hline Pressure drop in heat exchangers & $0.02 \mathrm{bar}$ \\
\hline
\end{tabular}

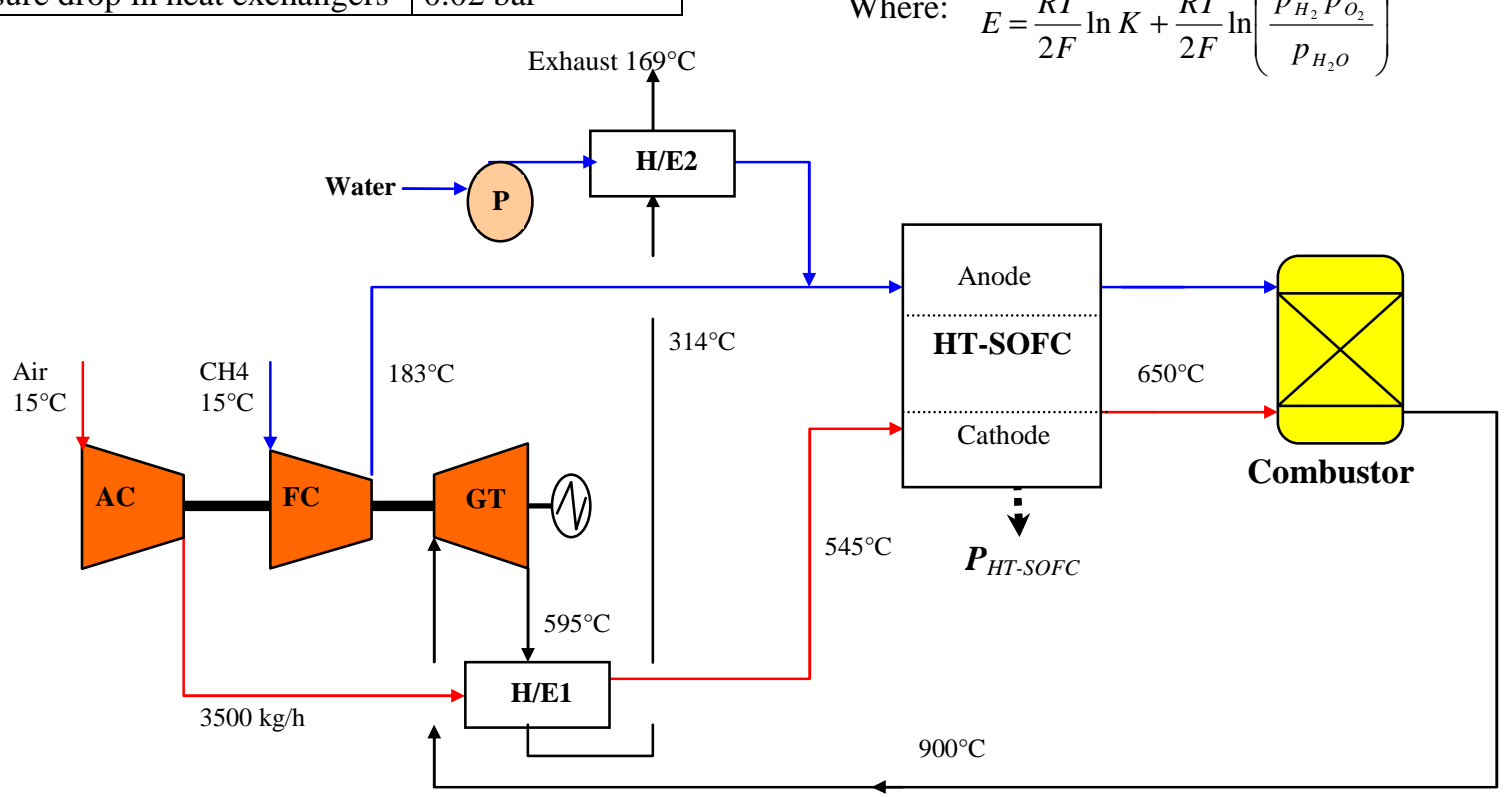

Fig. 1 . Configuration of basic HT-SOFC system

\section{Electrochemical Model}

In the models, the chemical reactions are assumed to be in equilibrium, i.e. that they occur instantaneously and reach the equilibrium condition spontaneously at each position. For SOFC models the electrochemical reactions are as follows:

$\frac{1}{2} O_{2}+2 e^{-} \rightarrow O^{2-}$ cathode

$\mathrm{H}_{2}+\mathrm{O}^{2-} \rightarrow \mathrm{H}_{2} \mathrm{O}+2 e^{-}$anode

$\mathrm{H}_{2}+\frac{1}{2} \mathrm{O}_{2} \rightarrow \mathrm{H}_{2} \mathrm{O}$ overall reaction

The high temperatures inside the SOFC stack can make it possible to reform the methane directly inside the cell if steam is provided at the inlet. The chemical reactions of fuel reforming and water-gas shift are as follows:

$\mathrm{CH}_{4}+\mathrm{H}_{2} \mathrm{O} \Leftrightarrow \mathrm{CO}+3 \mathrm{H}_{2}$

$\mathrm{CO}+\mathrm{H}_{2} \mathrm{O} \Leftrightarrow \mathrm{CO}_{2}+\mathrm{H}_{2}$

The electrochemical and water-gas shift reactions are exothermic, whereas fuel reforming is a strongly endothermic reaction.

\section{Description of the Models}

The fuel cell is treated as a single control volume to which the steady state flow energy equation is applied with the assumption of negligible change of kinetic and potential energy. In order to determine cell performance, the overpotential must be deducted from the Nernst potential ( $E$ ), which represents the ideal performance.

$$
V_{\text {cell }}=E-V_{\text {loss }}
$$

Where: $\quad E=\frac{R T}{2 F} \ln K+\frac{R T}{2 F} \ln \left(\frac{p_{\mathrm{H}_{2}} p_{\mathrm{O}_{2}}^{1 / 2}}{p_{\mathrm{H}_{2} \mathrm{O}}}\right)$ 


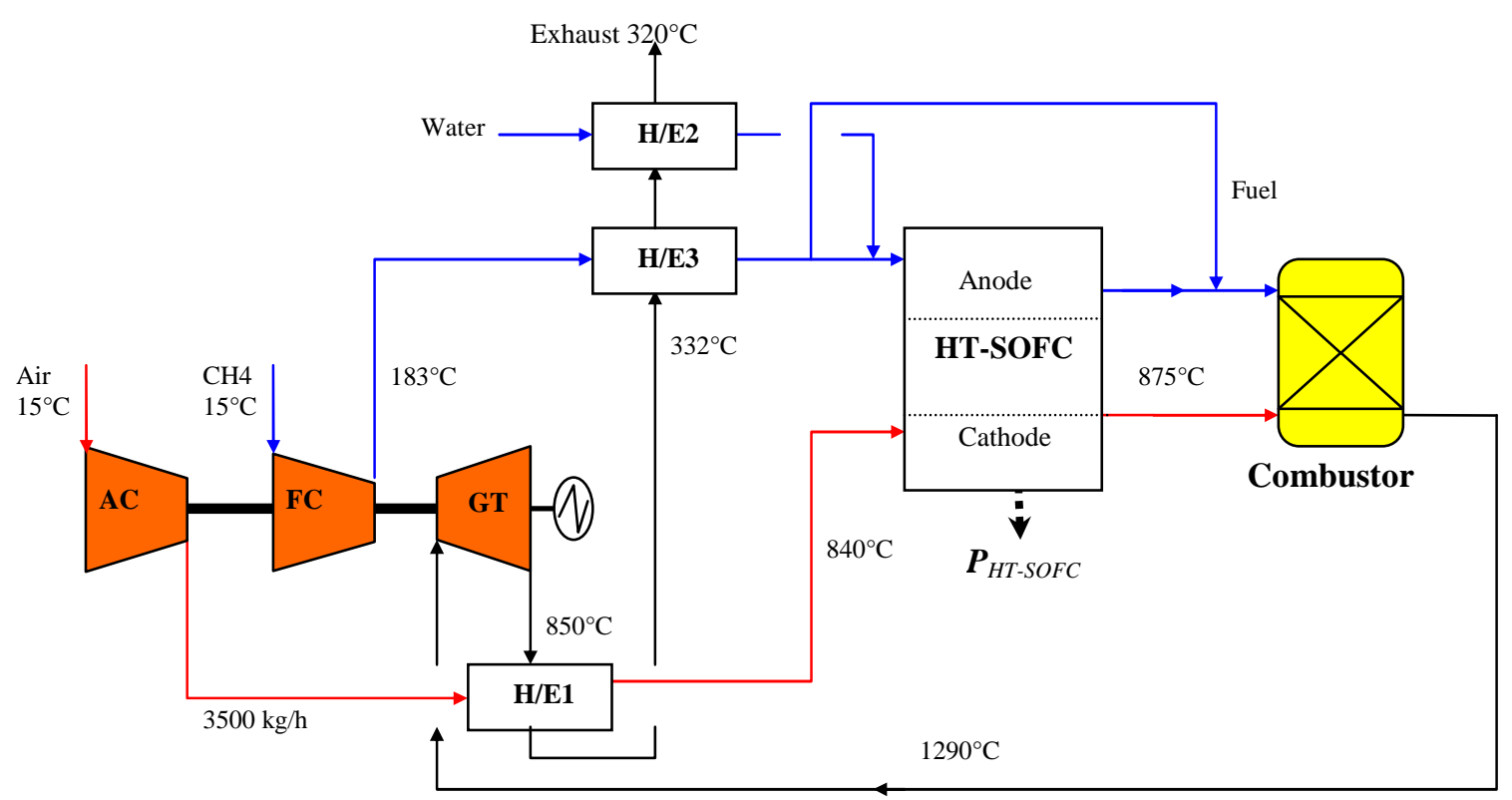

Fig. 2. Configuration of HT-SOFC/GT system

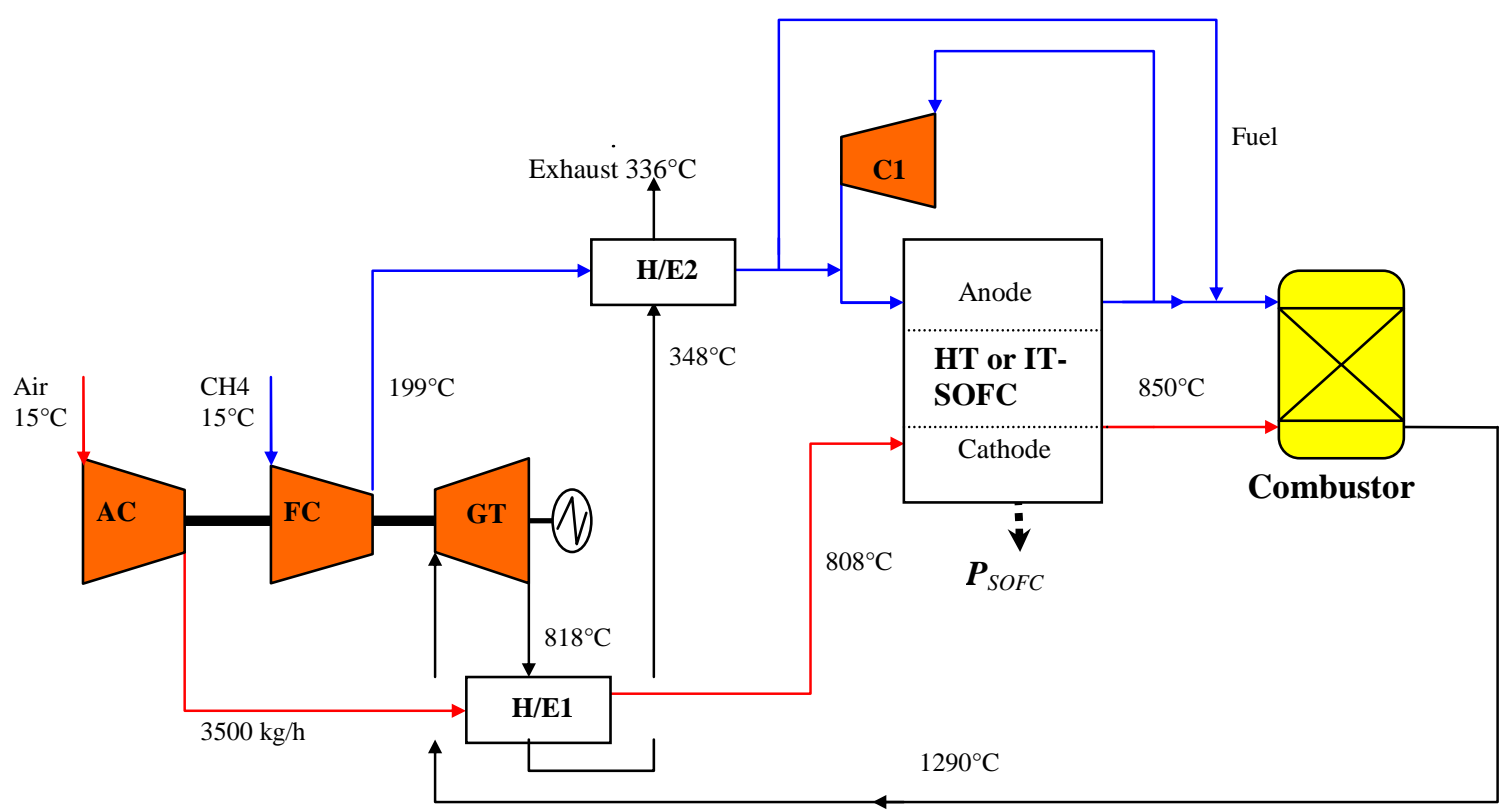

Fig. 3. Configuration of SOFC/GT with anode recycling systems 


\section{A. Evaluation of the overpotential in HT-SOFC}

The overpotential, which is a very important parameter in the analysis of fuel cell performance, is expressed by activation $\left(V_{\text {act }}\right)$, ohmic $\left(V_{\text {ohm }}\right)$ and concentration $\left(V_{\text {conc }}\right)$ overpotentials. Activation overpotential, which estimates losses due to slow electrochemical kinetics, is calculated as follows:

$V_{a c t}=\operatorname{ai} \exp \left(\frac{b}{T}\right)$

In this equation, $a=2.83 \times 10^{-4} \Omega \mathrm{cm}^{2}$ and $b=8360 \mathrm{~K}$ are the coefficients obtained by Solheim from experimental data from Umimura [4].

Ohmic overpotential, which estimates losses associated with ionic and electronic resistance throughout the fuel cell, can be calculated according to [5].

$V_{\text {ohm }}=i R_{t}$

The resistance of all materials used in the SOFC components can be calculated as follows:

$$
R_{t}=\frac{a \delta \exp \left(\frac{b}{T}\right)}{A}
$$

Where $a$ and $b$ are constants that are specific to the materials. $\delta$ is the equivalent thickness of the diffusion layer, and $A$ is the active area.

Concentration overpotential, which estimates losses due to mass transport limitations, becomes significant when amounts of current are drown from the cell, it can be calculated according to [5].

$$
V_{\text {conc }}=-\frac{\bar{R} T}{n_{e} F} \ln \left(1-\frac{i}{i_{L}}\right)
$$

\section{B. Evaluation of the overpotential in IT-SOFC}

The model of the IT-SOFC stack used in this paper is based on an existing IT-SOFC model [2]. In this model the cell utilises an electrolyte with a thickness of $25 \mu \mathrm{m}$, a 50$\mu \mathrm{m}$ thick cathode, and a $250-\mu \mathrm{m}$ thick anode. The cells are assumed to be stacked between bipolar interconnect plates. In contrast to HT-SOFC, which uses a ceramic interconnect, the IT-SOFC uses a lower operating temperature that allows the use of metal alloys.

It is difficult to break down reported cell characteristics in these individual contributions, and in the present context where the aim is stack and system modelling, all cell losses are lumped together in one equivalent resistance. The cell resistance is assumed to have the following temperature dependence [2]:

$$
R_{t o t}=\mathrm{A} \exp \left(\frac{\Delta \mathrm{E}}{\mathrm{K} \times T}\right)
$$

Where $\mathrm{T}$ represents the cell operating temperature and $\mathrm{K}$ is the Boltzmann constant. The activation energy $\left(\Delta \mathrm{E}=1.01 \times 10^{-19} \mathrm{~J}\right)$ and the pre-exponential factor $\left(\mathrm{A}=2.98 \times 10^{-4}\right)$ were chosen to fit the experimental data reported by [2].

\section{Results and Discussion}

\section{A. Performance of the base case SOFC cycle}

In this simulation, the performance of the basic HTSOFC system is evaluated. Please note that, the standard operating conditions of the cycle were operating temperature of $650^{\circ} \mathrm{C}$, and fuel utilisation rate of 50 $\%$. The fuel utilisation rate of the SOFC is low, because the methane is needed to be used in the combustion processes in the combustor. Result of the base case system shows that, the electrical outputs from the SOFC and gas turbine are $229.5 \mathrm{~kW}$ and $472.4 \mathrm{~kW}$, respectively. The net efficiency is $36.35 \%$. As it can be noted, the base case SOFC system (Fig. 1) gives a relatively low net efficiency. When the fuel utilisation rate is low, the electrical power produced by the SOFC decreases. In this base case of SOFC/GT system, the gas turbine is not able to supply enough heat to preheat air and vaporize water for steam reforming. Therefore, this problem needs solving: it is possible to increase fuel flow rate and bypass part of it to the combustor (see Fig. 2). This way also the current density or fuel flow rate to the fuel cell can be increased, as both flow rates become independent.

\section{B. Performance of the HT-SOFC/GT cycle}

A parametric study is performed to evaluate the effect of various parameters such as turbine inlet temperature, current density, operating pressure and fuel utilization on the performance of HT-SOFC system.

\section{Turbine inlet temperature (TIT)}

Figure 4 shows the relationship between the turbine inlet temperature (TIT) and the efficiency of the SOFC/GT system. The electrical outputs from the SOFC and gas turbine are increased simultaneously by increasing the turbine inlet temperature (see Fig 5). The net efficiency increases as shown in Fig. 4.

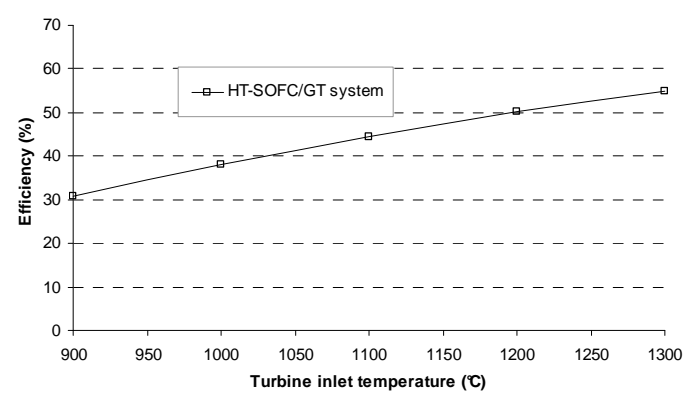

Fig. 4. Effect of turbine inlet temperature on efficiency 


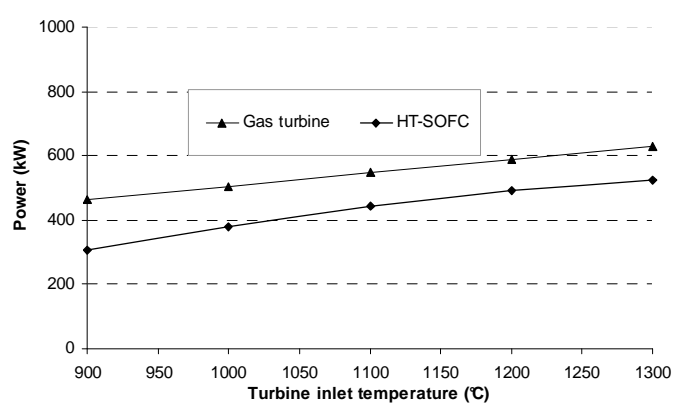

Fig. 5. Effect of the electrical outputs from the SOFC and gas turbine

\section{Current density}

The current density is an important parameter in cycle performance. From Figure 6 , it can be seen that the fuel cell itself has many trade-off options. A fundamental trade-off is determining where along the current voltage curve the cell should operate. As operating point moves up in voltage by moving (left) to a lower current density, the system becomes more efficient (see Fig 7) but requires a greater fuel cell area to produce the same amount of power. That is, by moving up the voltage current density line, the system will experience lower operating costs at the expense of higher capital costs. When the current density is very low, the amount of heat available is low. Therefore, the operating temperature and the overpotential of SOFC decrease and cause the increase of cell voltage of stack and the efficiency of SOFC stack.

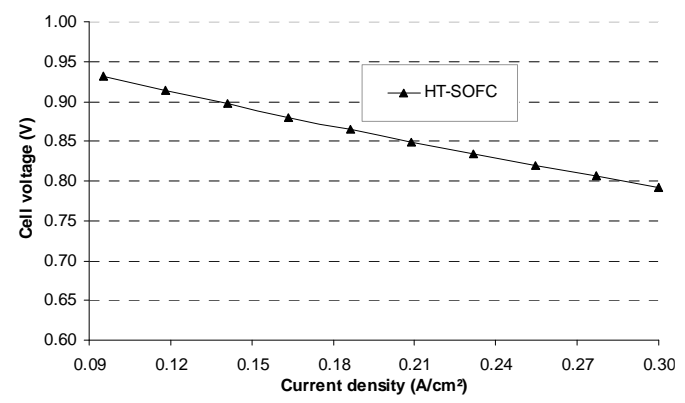

Fig. 6. Effect of current density on cell voltage

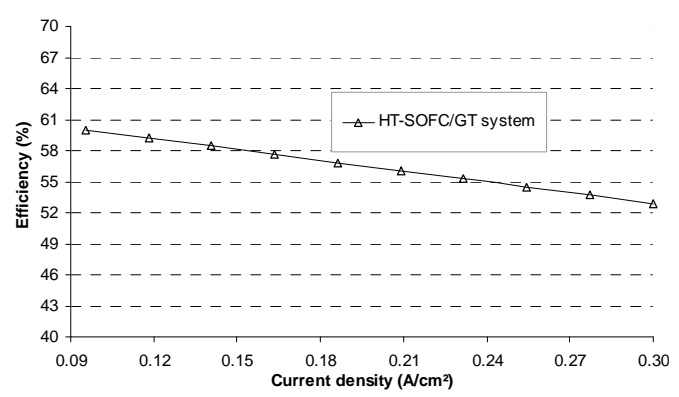

Fig. 7. Effect of current density on efficiency

\section{Operating pressure}

Figure 8 shows the relationship between the operating pressure and the efficiency of the SOFC/GT system.
Raising the operating pressure causes an increase in the Nernst potential. Also increasing the operating pressure leads to some decrease in the overpotential, resulting in an increase in the net efficiency in the system. The increase of the operating pressure causes an increase in the turbine inlet pressure, resulting in an increase of gas turbine output (see Fig. 9). When the operating pressure increases too much, however, the turbine nets output (turbine output minus compressor output) decreases and the cycle efficiency of the reaches a maximum. The turbine net output decreases, because the compressors power increases with the operating pressure increase. In particular, the higher the operating pressure, the higher the cell voltage determining a remarkable improvement of the electrical efficiency of the plant.

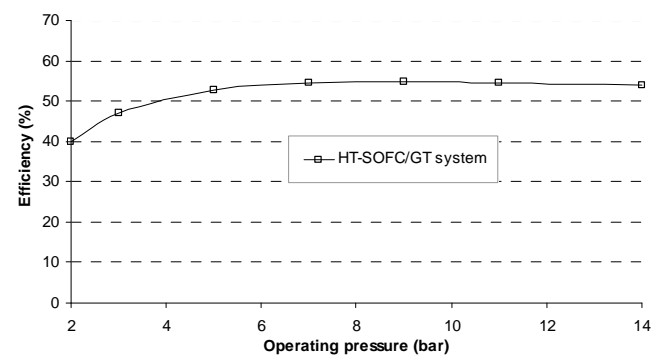

Fig. 8. Changes in efficiency with operating pressure

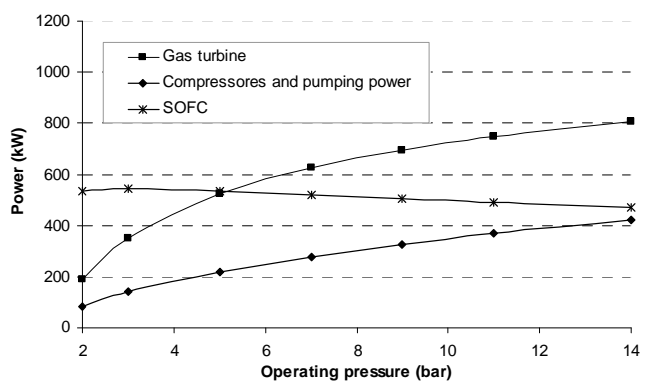

Fig. 9. Changes in power with operating pressure

\section{Fuel utilisation rate}

The fuel utilisation rate is one of the key parameters in the design of a fuel cell stack. The target is generally to keep its value at a highest possible level, even if this is almost never possible because of the technological and economical constraints. Figure 10 shows the changes in the efficiency of the system with fuel utilisation rate. When the fuel utilisation rate is very high, a majority of the amount of hydrogen produced by the internal reforming reaction is consumed within the fuel cell. Thus, the energy converted at the SOFC stack increases with raising the fuel utilisation rate. Increases in the fuel utilisation rate bring decreased cell voltage. The efficiency improvement from higher fuel utilisation rate is significant, resulting in increasing the electrical output of the SOFC stack.

\section{Fuel recirculation rate}

Figure 11 shows the changes in the net efficiency of the HT-SOFC/GT system with fuel recirculation rate. By 


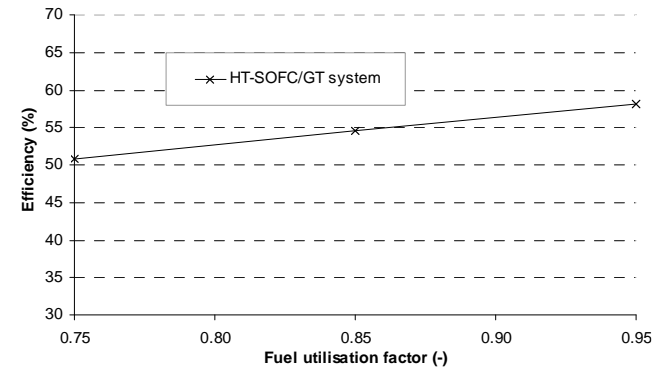

Fig. 10. Changes in net efficiency with fuel utilisation rate

increasing the fuel recirculation rate the $\mathrm{CH}_{4}$ concentration in the outlet of the SOFC anode goes down (see Fig. 12). This means an increase in the mass flow rate of steam results in moving the reforming and gas shift reaction equilibrium to the $\mathrm{H}_{2}$ side. Increase in the fuel recirculation rate leads to an increasing the electrical output of the SOFC stack, resulting in an increase in net efficiency of the system.

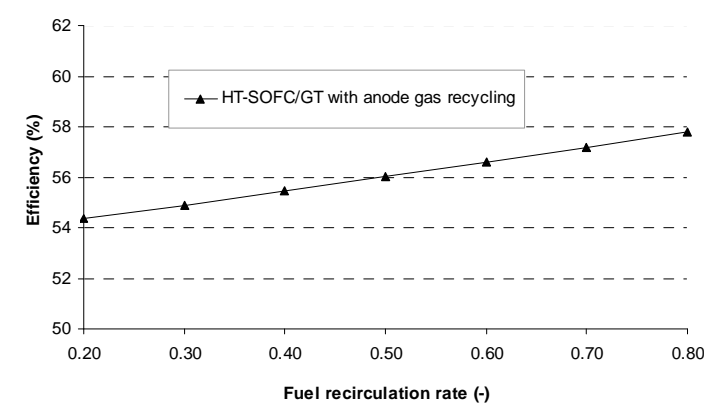

Fig. 11. Effect of fuel recirculation rate on efficiency

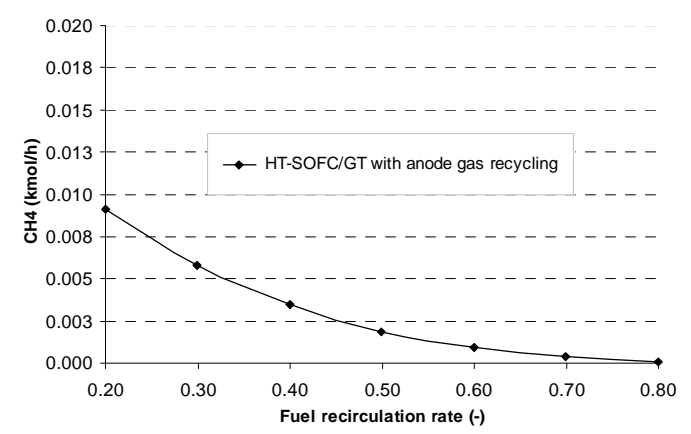

Fig. 12. The $\mathrm{CH}_{4}$ concentration in the outlet of the SOFC

\section{Comparison of Performance between the (HT and IT) SOFC with anode gas recycling cycles}

Figure 13 shows the effect of operating temperature on efficiency of the cycle for both HT-SOFC and IT-SOFC. The operating temperature was changed through changing the heat input in the cathode flow, by varying the size of the heat exchanger $\mathrm{H} / \mathrm{E} 1$. Increasing the operating temperature of the SOFC stack decreases the electrolyte resistance in the SOFC stack and thus the efficiency of the fuel cell increases. The gas turbine power output is fairly constant as TIT is kept constant. The efficiency for the IT-SOFC is found be the higher than the efficiency for the HT-SOFC. This is because the cell voltage is higher in the IT-SOFC stack than in the HT-SOFC stack. The IT-SOFC has a higher cell voltage than the HT-SOFC, because of lower losses of a metal alloys, which is utilize as the electrolyte in the IT-SOFC model.

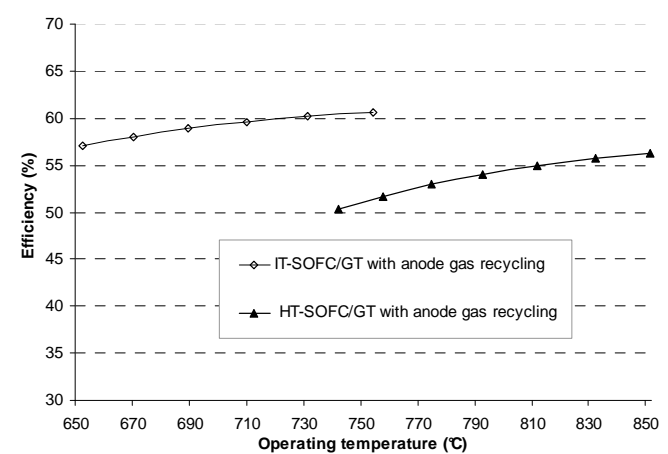

Fig. 13. Effect of operating temperature on efficiency of the SOFC/GT systems

\section{CONCLUSIONS}

Several of SOFC cycles are proposed and investigated. A parametric study is performed to evaluate the effect of various parameters such as turbine inlet temperature, current density, operating pressure and fuel utilization on the performance of HT-SOFC system. Furthermore, the HT-SOFC and the IT-SOFC cycles are simulated in order to evaluate and compare their performances. The simulation results show that the electrical outputs from the SOFC and gas turbine are increased simultaneously by increasing the turbine inlet temperature. Also cycle efficiency increased when operating pressure or fuel utilisation rate increase. Moreover, the efficiency for the IT-SOFC cycle is found be the higher than the efficiency for the HT-SOFC cycle.

\section{Acknowledgement}

The authors acknowledge Tripoli University, Tripoli, Libya for the support of this work

\section{References}

[1] Calise F, Dentice d'Accadia M, Palombo A, Vanoli L. Simulation and exergy analysis of a hybrid Solid oxide fuel cell (SOFC)-Gas Turbine system J. Energy 2006; 31: 32783299.

[2] Plasson J, Selimovic A, Hendriksen P. Intermediate temperature SOFC in gas turbine cycles. J. ASME 2001; GT: 0091.

[3] Musa A, De Paepe M. Performance of combined internally reformed intermediate/high temperature SOFC cycle compared to internally reformed two-staged intermediate temperature SOFC cycle. International Journal of Hydrogen Energy 2008; 3: 4665-4672.

[4] Stiller C. Design, Operation and Control Modelling of SOFC/GT Hybrid Systems. Doctoral Thesis, Norwegian University of Science and Technology, Norway, 2006; pp. 41-42.

[5] Chan SH, Ho HK, Tian Y. Modelling of simple hybrid SOFC and Gas Turbine Power Plant. J. Power Sources 2002; 109: 111-120.

[6] Zhang, X., Chan, S.H., Li, G; Ho, H.K; Li, J; Feng, Z; “A review of integration strategies for solid oxide fuel cells", Journal of Power Sources 2010; 195:685-702.

[7] Chan SH, Low CF, Ding OL. Energy and exergy analysis of simple solid-oxide fuel cell power systems J. Power Sources 2002; 103: 188-200. 